\title{
Susceptibility of Populus balsamifera to Septoria musiva: A Field Study and Greenhouse Experiment
}

Jared M. LeBoldus and Peter V. Blenis, Department of Renewable Resources, University of Alberta, Edmonton, AB T6G 2H1, Canada; Barb R. Thomas, Alberta-Pacific Forest Industries Inc., Boyle, AB T0A 0M0, Canada; Nicolas Feau, INRA, UMR BioGeCo, BP 81, 71, Avenue Edouard Bourlaux, 33883 Villenave d'Ornon Cedex, France; and Louis Bernier, Centre d'Étude de la Forêt, Université Laval, Québec, QC G1V 0A6, Canada

\begin{abstract}
LeBoldus, J. M., Blenis, P. V., Thomas, B. R., Feau, N., and Bernier, L. 2009. Susceptibility of Populus balsamifera to Septoria musiva: A field study and greenhouse experiment. Plant Dis. 93:1146-1150.

A greenhouse inoculation experiment and field study were conducted to determine the cause of an outbreak of Septoria musiva cankers on Populus balsamifera in a northern Alberta plantation. Four clones of $P$. balsamifera, five clones of putatively resistant $P$. deltoides, and one susceptible hybrid poplar clone, Northwest, were inoculated with seven isolates identified as $S$. musiva. Four of the isolates were from P. balsamifera in Alberta and the others were from P. deltoides in Quebec. Results indicated that disease severity was similar for Alberta and Quebec isolates $(P=$ $0.243)$ and that $P$. balsamifera had the greatest mean disease severity $(\bar{x}=4.20), P$. deltoides had the lowest $(\bar{x}=2.76)$, and Northwest was intermediate $(\bar{x}=3.45)$. A genetic analysis comparing six polymorphic polymerase chain reaction restriction fragment length polymorphism loci and the mitochondrial small subunit ribosomal DNA sequences of the seven isolates indicated that the Alberta population was made up of at least three distinct genotypes. Canker incidence and age on Northwest and 56 different clones of $P$. balsamifera in a plantation were recorded. Canker incidence $(P=0.726)$ and the canker age distributions $(P=0.994)$ were similar for the two species. In conclusion, contrary to what has been reported in the literature, P. balsamifera appears to be quite susceptible to Septoria canker.
\end{abstract}

Septoria musiva Peck (teleomorph = Mycosphaerella populorum G.E. Thomps.), a fungal pathogen of Populus spp., has caused severe damage and even plantation failure across eastern Canada, the Prairie Provinces, and the north-central United States $(2,8,16,22)$. This pathogen causes both leaf spots, which, in the case of severe disease, may result in premature defoliation, and stem cankers, which increase the risk of wind breakage (16). A closely related species, S. populicola Peck (teleomorph $=M$. populicola $\mathrm{C}$. H. Thomps.), also causes leaf spots on native Populus spp. and has caused stem cankers on Populus trichocarpa Torr. \& Gray $(14,15)$ and P. balsamifera L. (24) under certain conditions.

The expansion of poplar cultivation in British Columbia's Fraser Valley (3), Quebec's bioclimatic domains 3 and 4 (15), and South America (1) has been accompanied by an increase in damage caused by $S$.

Corresponding author: Jared M. LeBoldus E-mail: jaredı@ualberta.ca

Accession numbers FJ803984, FJ803985, FJ803986, FJ803987, and FJ803988.

Accepted for publication 5 July 2009.

doi:10.1094/PDIS-93-11-1146

(C) 2009 The American Phytopathological Society musiva. Furthermore, in 2006, a high incidence of stem infections was observed on $P$. balsamifera in a plantation within its native range in northern Alberta. Although both Sivanesan (19) and Sinclair and Lyon (18) state that Populus spp., in general, are hosts of S. musiva and that this pathogen demonstrates no physiological specialization, the high incidence of stem infection was unexpected given that, to the authors' knowledge, natural stem infection of $P$. balsamifera within its native range has not been reported $(19,22)$. Consequently, it was important to determine whether the recent appearance of stem cankers on $P$. balsamifera, a native species, is due to an environmental anomaly such as a wave year (17) or if novel isolates of $S$. musiva or $S$. populicola with enhanced ability to infect this host have recently arisen.

The overall goal of this project was to determine the cause of an outbreak in a $P$. balsamifera clonal growth trial in northern Alberta. Conidial morphology and speciesspecific markers were used to determine which Septoria spp. were responsible for the outbreak. A greenhouse experiment was conducted to determine whether Alberta isolates (i) exhibited above-average virulence relative to isolates from Quebec which had been evaluated previously for their virulence (10) and genetic diversity (5), (ii) were specific to $P$. balsamifera, and (iii) were able to incite disease on another putatively resistant species, $P$. deltoides Rydb. var. occidentalis. A field study was conducted to examine potential environmental causes of the outbreak. The canker age distribution was used to determine whether a wave year phenomenon (17) may have been responsible for the outbreak. S. musiva isolates were compared in terms of six polymorphic loci and mitochondrial small subunit ribosomal DNA (mtSSU-rDNA) sequences to determine whether the outbreak was caused by a single highly virulent isolate or a group of isolates.

\section{MATERIALS AND METHODS}

Part I: Inoculation experiment. Poplar culture. Branch cuttings from four clones of $P$. balsamifera, five clones of $P$. deltoides, and one hybrid poplar clone, $P$. deltoides $\times P$. balsamifera Sarg. cv. Northwest, were collected from research trials at the Alberta-Pacific Forest Industries Inc. (Al-Pac) mill site in northern Alberta (approximate location: $54^{\circ} \mathrm{N}$, $\left.112^{\circ} \mathrm{W}\right)$. All branch collections were carried out in January 2007 from the previous year's growth. The branch tissue was removed and cut into $10-\mathrm{cm}$ sections that were soaked in deionized water for $48 \mathrm{~h}$ at $4^{\circ} \mathrm{C}$ (4). These cuttings were planted into 12-cm rootrainers (Spencer-Lemaire Rootrainers; Spencer-Lemaire Industries, Edmonton, AB, Canada) containing Metromix 290 growing media (Terra-Lite 2000 series; WR Grace and Company, Ajax, ON, Canada) such that only the topmost bud remained exposed above the media surface (4).

After planting, the cuttings were placed into a greenhouse maintained at 20 and $15^{\circ} \mathrm{C}$ (day and night) with an 18 -h photoperiod supplemented with artificial lights. The irradiance varied with cloud cover but was, on average, approximately $450 \mu \mathrm{mol}$ photons $\mathrm{m}^{-2} \mathrm{~s}^{-1}$ photosynthetically active radiation (PAR) at the rootrainer level. During the first 59 days, plants were fertilized biweekly with a 500 ppm solution of 15-30-15 fertilizer (Plant Products Company Ltd., Brampton, ON, Canada). At the end of the initial 59-day growth period, 40 trees from each clone were transplanted from the rootrainers into 15-by-18-cm plastic pots (Listo Products Ltd., Vancouver, BC, Canada) containing Metromix 290 growing media amended with Nutri- 
cote 100-day slow-release 13-13-13 fertilizer $\left(6.5 \% \quad \mathrm{NO}_{3}-\mathrm{N}, 6.5 \% \quad \mathrm{NH}_{4}-\mathrm{N}, \quad 13 \%\right.$ $\mathrm{P}_{2} \mathrm{O}_{5}, 13 \% \quad \mathrm{~K}_{2} \mathrm{O}, 1.2 \% \mathrm{Mg}, 0.02 \% \mathrm{~B}$, $0.05 \% \mathrm{Cu}, 0.2 \%$ chelated $\mathrm{Fe}, 0.06 \% \mathrm{Mn}$, $0.02 \% \mathrm{Mo}$, and $1.3 \%$ EDTA; Plant Products Company Ltd.) at $2.73 \mathrm{~g} \mathrm{liter}^{-1}$.

Pathogen culture. The seven isolates of Septoria used in this experiment originated from Quebec and Alberta. Two of the three Quebec isolates came from the University of Laval fungal culture collection as single-spore cultures. The remaining isolate was obtained from a leaf with $S$. musiva symptoms collected from a $P$. deltoides Bartr. Ex Marsh. var. deltoides tree near Quebec City. Leaf spots with pycnidia visible under a dissecting microscope were used for isolation and only one leaf spot per leaf was used. Isolations were performed by placing and then removing approximately $5 \mu \mathrm{l}$ of sterile distilled water onto a leaf spot with a micropipette. This drop of water, containing any conidia that may have been present on the surface of the leaf spot, was placed onto a petri dish containing corn meal agar (CMA; Difco, Franklin Lakes, NJ) amended with chloramphenicol (Sigma-Aldrich, St. Louis) at $300 \mathrm{mg} \mathrm{liter}^{-1}$ and streptomycin (SigmaAldrich) at $25 \mathrm{mg} \mathrm{liter}^{-1}$. Approximately 1 $\mathrm{ml}$ of sterile water was added and each plate was swirled several times to spread the solution over the surface of the CMA. These plates were then sealed with Parafilm (Structure Probe Inc., West Chester, PA) and placed on a light bench under Gro-Lux wide-spectrum fluorescent bulbs (Sylvania; Osram GmbH, Munich) at room temperature, where they received $24 \mathrm{~h}$ of light. After 7 days, any sporulating fungal colonies were transferred to a second CMA plate. Once a single fungal colony arose, it was transferred to $\mathrm{K}-\mathrm{V} 8$ growth media (180 $\mathrm{ml}$ of V8 juice [Campbell Soup Company, Camden, NJ], $2 \mathrm{~g}$ of calcium carbonate, $20 \mathrm{~g}$ of agar [Difco], and $820 \mathrm{ml}$ of deionized water) and allowed to grow until sporulation occurred.

Alberta isolates were obtained by collecting Septoria-like cankers from dormant $P$. balsamifera trees at the Al-Pac mill site in northern Alberta. Cankers were first soaked in a $5 \% \mathrm{NaClO}$ solution for $120 \mathrm{~s}$ and than rinsed with sterile distilled water. The bark was then removed from the canker, exposing the margin between healthy and necrotic tissue. From this margin, a 5$\mathrm{mm}$ sliver of necrotic tissue was removed and placed on a petri dish with $S$. musiva media (SMM; K-V8 growing media amended with chloramphenicol and streptomycin at 300 and $25 \mathrm{mg} \mathrm{liter}^{-1}$, respectively) (20). These plates were then sealed with Parafilm and placed on the light bench described above. After 7 days, any sporulating fungal colonies were transferred to a second SMM plate. Once a single fungal colony arose, it was transferred to K-V8 growth media and allowed to grow until sporulation occurred. For both Alberta and Quebec isolates, species identity was confirmed using both conidial morphology (19) and an internal transcribed spacer diagnostic developed by Feau et al. (7).

Cultures were stored at $-90^{\circ} \mathrm{C}$ in cryogenic vials (Nalgene Labware, Rochester, NY) containing $300 \mu \mathrm{l}$ of $50 \%$ glycerol and $700 \mu \mathrm{l}$ of potato dextrose broth (PDB; Difco). As needed, two vials of each isolate were removed from cold storage and allowed to warm to room temperature. Each tube was poured onto a petri dish of K-V8 growth media and sealed with Parafilm. These plates were placed on the light bench, described above, for 5 days.

For each isolate, four 5-mm sporulating masses of mycelium were excised from the plate with the most growth and placed on $\mathrm{K}-\mathrm{V} 8$ growing media. Eight similar plates were created for each isolate. These plates were sealed and placed on the light bench, as described above. After 14 days, the five plates with the most growth and sporulation were used as inoculum for the experiment.

Experimental design. The seven isolates were nested within two provinces of origin (Alberta or Quebec) and the 10 clones were nested within three "species" types (P. deltoides, P. balsamifera, and Northwest). The experimental design was a randomized complete block with five blocks, each consisting of 80 randomly arranged trees. The seven isolates (plus one uninoculated control) were randomly assigned to trees so that each combination of 10 clones and seven isolates (plus control) occurred once per block. In total, there were 400 trees in the experiment.

Inoculation. Inoculations were carried out 56 days after the trees had been planted. One petri dish was used per isolate per block. The plants were inoculated by first removing the third fully extended leaf from the shoot apex (13). A sporulating plug of mycelium measuring $5 \mathrm{~mm}$ in diameter, with excess agar removed, was then placed over the wound and wrapped in Parafilm (13). Uninoculated controls were treated in the same manner except that sterile K-V8 agar rather than mycelium was used. Finally, the Parafilm was removed from all stems 14 days after inoculation (23).

Forty-nine days after inoculation, a 30$\mathrm{cm}$ stem section, centered at the inoculation site, was removed. These sections were labeled by clone, isolate, and block number, placed in paper bags, and stored at $4^{\circ} \mathrm{C}$ until disease severity was evaluated. Cankers were ranked on a 1-to-5 scale using a dissecting microscope $(1=$ wound healed with no callus formation, 2 = callus without necrosis, $3=$ necrosis contained by callus, $4=$ necrosis extending beyond callus, and $5=$ complete encirclement) within 2 weeks of harvest. Five cankers from each clone were selected and reisolated onto SMM to confirm the presence of S. musiva.
Statistical analysis. Statistical analyses were conducted using the SAS MIXED procedure (12) with heterogenous variances modeled as needed; in all cases significance was assessed at $P \leq 0.05$. Beginning with the initial model, the likelihood ratio $\chi^{2}$ test was used to determine the significance of random factors. These factors were evaluated in the following sequence: (i) the two-way interaction of clone (species) $\times$ isolate (province), clone (species) $\times$ province, and isolate (province) $\times$ species; and (ii) the main effects of clone (species) and isolate (province). For both (i) and (ii), the order of testing was determined by the magnitude default $Z$ test, with the factors with the largest $P$ value being tested first. Nonsignificant random factors were removed from the model at each step. The significance of species, province of origin, and the interaction of species-province were assessed based on their significance in the final model. In addition, two post-hoc tests were conducted. First, $t$ tests were used to make pairwise comparisons of the average disease severity of $P$. balsamifera, $P$. deltoides, and Northwest. Second, the average disease severity of each clone was determined using best linear unbiased predictors (BLUPs) (12) and an $F$ test was used to test the null hypothesis of equal clonal variances between the two species.

Part II. Molecular analysis. $m t S S U$ rDNA sequencing. Total genomic DNA was extracted directly from lyophilized mycelium using the Qiagen DNeasy plant mini kit (Qiagen Inc., Valencia, CA). The mtSSU-rDNA gene was amplified and sequenced using the NMS1 and NMS2 primers described by Li et al. (11). Polymerase chain reactions (PCRs) were performed in an Eppendorf Master Cycler (Eppendorf Canada, Mississauga, ON, Canada) using Phusion polymerase (New England Biolabs Inc., Ipswich, MA) with the following parameters: $2 \mathrm{~min}$ at $98^{\circ} \mathrm{C}$, $30 \mathrm{~s}$ at $98^{\circ} \mathrm{C}, 30 \mathrm{~s}$ at $55^{\circ} \mathrm{C}$, and $30 \mathrm{~s}$ at $72^{\circ} \mathrm{C}$. Cycling was performed for $30 \mathrm{cy}-$ cles and a final extension was conducted at $72^{\circ} \mathrm{C}$ for $10 \mathrm{~min}$. Sequencing reactions were conducted using the BigDye v3.1 cycle sequencing kit (Applied Biosystems Inc., Foster City, CA), and resolved on an AB 3730 DNA Analyzer. NMS1 and NMS2 sequences were aligned in Seqman (Lasergene, DNA Star) and haplotypes determined by multiple alignment in MegAlign (Lasergene, DNA Star).

Internal transcribed spacer diagnostic. For both the internal transcribed spacer (ITS) diagnostic and PCR restriction fragment length polymorphism (RFLP) analysis, total genomic DNA was extracted directly from lyophilized mycelium by the hexadecyltrimethylammonium bromide (CTAB) method according to Zolan and Pukkila (25). Total DNA was diluted 30fold in nanopure water and used as a template for PCR amplifications. 
The ITS locus of the nuclear rDNA region from each of the Septoria isolates was amplified with the species-specific primer sets (Smusf/Smusr and Spopf/ Spopr) described by Feau et al. (7). PCR amplifications and cycles were carried out in an MJ Research thermal cycler model PTC100 (MJ Research, Incline Village, NV) according to the protocol modifications made at the University of Wisconsin-Madison as described by Feau et al. (7). PCR fragments were separated by electrophoresis using $1 \%$ Tris-acetate-EDTA (TAE) agarose gels. The gels were stained with ethidium bromide for $10 \mathrm{~min}$, visualized, and photographed under UV light.

PCR-RFLP loci analysis. Six polymorphic loci (Smr2, Smr3, Smr4, Smr6, Smr7, and Smr11) identified by Feau et al. (6) were targeted for PCR-RFLP analyses. For each assay, PCR reactions were performed in a 20- $\mu$ l reaction volume consisting of 2 $\mu \mathrm{l}$ of DNA template, $0.2 \mu \mathrm{M}$ each primer, $0.5 \mathrm{mM}$ each dNTP (GE Healthcare UK \& Ireland, Little Chalfont, UK), $1.5 \mathrm{mM}$ $\mathrm{MgCl}_{2}$, and $0.5 \mathrm{U}$ of Platinum Taq DNA polymerase (Invitrogen Corporation, Carlsbad, CA) in a $1 \times$ Taq DNA polymerase buffer $(20 \mathrm{mM}$ Tris- $\mathrm{HCl}, \mathrm{pH}$, and $50 \mathrm{mM}$ $\mathrm{KCl}$ ), with thermocycling conditions as follows: denaturation for $3 \mathrm{~min}$ at $94^{\circ} \mathrm{C} ; 35$ cycles at $94^{\circ} \mathrm{C}$ for $30 \mathrm{~s}, 30 \mathrm{~s}$ at $53^{\circ} \mathrm{C}$ for each primer pair, and $72^{\circ} \mathrm{C}$ for $70 \mathrm{~s}$; with a final extension of $5 \mathrm{~min}$ at $72^{\circ} \mathrm{C}$. Each PCR product $(5 \mu \mathrm{l})$ was then digested overnight in a final volume of $10 \mu \mathrm{l}$ supplemented with $1 \times$ buffer and $0.1 \mathrm{U}$ of restriction enzyme, and restriction fragments were visu- alized on 2\% TAE agarose gels, as described above.

Part III. Field study. Study description. A field study was conducted in a 7-yearold clonal trial located at the Al-Pac mill site in northern Alberta, described above. The trial was a randomized complete block design with 20 blocks. Each block consisted of 56 clones of $P$. balsamifera randomly assigned to single-tree plots. The $P$. balsamifera clones had been collected from various locations across northern Alberta and British Columbia. The entire trial was bordered by two rows of the hybrid clone Northwest. In January 2007, two blocks with 112 P. balsamifera and 80 Northwest trees were harvested, delimbed, and evaluated for stem canker incidence, stem canker age, and whether or not the tree was alive, dead, or broken at the time of harvest. Canker age was determined by sectioning each canker at the midpoint, sanding the surface of those sections, and counting the number of growth rings since the first symptom of infection. Isolations were also conducted from 10 cankers to confirm the presence of $S$. musiva.

Statistical analysis. The SAS MIXED procedure (12) was used to determine whether there were significant differences in the number of cankers per tree between $P$. balsamifera and Northwest and among $P$. balsamifera clones; in all cases, significance was assessed at $P \leq 0.05$. The Kolmogorov-Smirnov two-sample test was conducted to compare the canker age distributions of $P$. balsamifera and Northwest. A second analysis was performed to determine whether there was a significant

Table 1. Analysis of variance with the variance components partitioned among sources

\begin{tabular}{lcccc}
\hline Source of variation & df & $\boldsymbol{P}$ value & $\begin{array}{c}\text { Variance } \\
\text { estimate }\end{array}$ & $\begin{array}{c}\text { Proportion } \\
\text { of explained } \\
\text { variance }\end{array}$ \\
\hline Block $^{\mathrm{v}}$ & 4 & - & 0.005 & 0.03 \\
Species $^{\mathrm{w}}$ & 2 & $<0.001$ & - & - \\
Province $^{\mathrm{x}}$ & 1 & 0.243 & - & - \\
Species $\times$ province $_{\text {Clone }(\text { species) }}^{\mathrm{v}}$ & 2 & 0.412 & - & - \\
Isolate $^{\mathrm{v}}($ province) & 18 & $<0.001$ & $0.08^{\mathrm{y}}$ & 0.83 \\
Species $\times$ isolate $\left(\right.$ province) $_{\text {Clone }(\text { species) } \times \text { province }}$ & 12 & $<0.001$ & 0.027 & 0.14 \\
Clone $\left(\right.$ species) $\times$ isolate (province) $_{\text {Residual }}^{\mathrm{v}}$ & 24 & 0.371 & - & - \\
Total & 18 & 0.372 & - & - \\
\hline
\end{tabular}

${ }^{v}$ Variance components included in the final model.

${ }^{\mathrm{w}}$ Populus balsamifera, P. deltoides, and Northwest.

$x$ Alberta and Quebec.

${ }^{y}$ Clone within species variance estimate is an average of the variance estimate for $P$. deltoides and $P$. balsamifera.

${ }^{\mathrm{z}}$ Residual values varied with isolate. The value reported was calculated by averaging the variances of the seven isolate residuals.

Table 2. Estimated difference in mean disease severity, 95\% confidence interval (CI), and the corresponding $P$ values among the three species

\begin{tabular}{lccc}
\hline Comparison & Estimate & 95\% CI & P value \\
\hline Populus balsamifera-Northwest & 0.75 & \pm 0.60 & 0.025 \\
Northwest-P. deltoides & 0.70 & \pm 0.22 & $<0.001$ \\
$P$. balsamifera-P. deltoides & 1.44 & \pm 0.63 & 0.004 \\
\hline
\end{tabular}

difference in disease incidence between trees collected in Alberta and British Columbia, and to compare disease incidence among provenances nested within province and disease incidence of clones nested within provenance.

\section{RESULTS}

Part I. Inoculation experiment. Alberta and Quebec isolates induced similar levels of disease $(P=0.243$; Table 1). However, $P$. deltoides, $P$. balsamifera, and the hybrid clone Northwest all sustained different disease severities $(P<0.001$; Table 2). The mean disease severity of the five $P$. deltoides clones $(\bar{x}=2.76)$ was the lowest, the four P. balsamifera clones ( $\bar{x}=$ 4.20) was the highest, and the hybrid clone Northwest $(\bar{x}=3.45)$ was intermediate (Table 2). There were significant effects of isolate $(P<0.001$; Table 1$)$, and clone (species) $(P<0.001$; Table 1$)$, whereas the clone (species) $\times$ isolate (province) interaction $(P=0.751$; Table 1$)$, the species $\times$ isolate (province) interaction $(P=0.371$; Table 2), and the clone (species)-province interaction $(P=0.372$; Table 1$)$ were not significant. Finally, there was less variability among $P$. deltoides $\left(\sigma_{\mathrm{D}}=0.014\right)$ clones than among $P$. balsamifera $\left(\sigma_{\mathrm{B}}=0.127\right)$ clones $(P=0.001)$.

Part II. Molecular analysis. The species-specific markers described by Feau et al. (7) in the ITS region indicated that all seven isolates were $S$. musiva. There were no differences in the mtSSU-rDNA sequences among the four Alberta isolates, nor were there differences between the two Quebec isolates (Table 3). There was, however, a single base substitution difference shared by the Quebec isolates differentiating them from those collected in Alberta (Table 3). On the other hand, the six PCR-RFLP loci indicated that isolates APB4, APB3, and SO3 were different, whereas APB1, APB2, and QC8 could not be differentiated (Table 3). Based on the combined sequence data and the PCRRFLP loci analysis, there were at least three genetically distinct isolates from Alberta and two from Quebec (Table 3).

Part III. Field study. All trees sampled in the field study had at least one stem canker. Incidence ranged from 1 to 18 cankers per tree, with a mean of 7.5 , for Northwest and from 1 to 28 cankers per tree, with a mean of 6.0 , for $P$. balsamifera. Neither the mean number $(P=0.726)$ nor the age distribution of cankers $(P=$ $0.994)$ differed between $P$. balsamifera and Northwest (Fig. 1). The variability in canker incidence among $P$. balsamifera clones $\left(\sigma_{\mathrm{B}}=5.35\right)$ was significantly greater than 0 $(P<0.001)$. Furthermore, there was neither a significant effect of province $(P=$ $0.658)$ nor of provenance (province) $(P=$ 0.281 ) in terms of disease incidence, whereas clones (provenance) were significantly different $(P<0.001)$. S. musiva, identified based on conidial morphology 
(19), was successfully isolated from 4 of the 10 cankers sampled.

\section{DISCUSSION}

Several authors have reported that both $S$. musiva and $S$. populicola can incite stem infections on P. balsamifera $(15,24)$. However, the ITS diagnostic and conidial morphology clearly indicate that the pathogen $S$. musiva is responsible for this outbreak.

The mean disease severity $(\bar{x}=4.20)$ and canker frequency $(\bar{x}=6.0)$ observed on $P$. balsamifera in the two studies described above clearly contradict Waterman's (22) statement and Bier's findings (2) that $P$. balsamifera is resistant to stem infection caused by $S$. musiva within its natural range. Although previous authors have had some success inoculating P. balsamifera following wounding, the frequency of trees infected was relatively low (0 to $31.6 \%$ ) (24) or completely healed over (2) compared with the high frequency of infected trees $(100 \%)$ observed in our field study. Furthermore, to our knowledge, there have been no reports of Septoria canker on unwounded $P$. balsamifera or on $P$. balsamifera within its natural range. The question remains as to why this outbreak in a plantation has occurred.

The first possibility is that this outbreak was caused by a single isolate or a group of isolates with an enhanced ability to incite disease The hypothesis that a single highly virulent isolate was responsible for the outbreak can easily be rejected because at least three of the four Alberta isolates collected from $P$. balsamifera cankers were genetically different (Table 3) and they differed in their ability to incite disease $(P$ $<0.001)$. Alternatively, the outbreak may have been caused by a group of extraordinarily virulent isolates. However, the lack of a difference in disease severity between the Alberta and Quebec isolates $(P=$ 0.243 ); together with the relatively low mean disease severity on $P$. deltoides $(\bar{x}=$ 2.76) compared with either the hybrid clone Northwest or the four P. balsamifera clones (Table 2), precludes this hypothesis.

A third consideration is that the outbreak was caused by isolates that are specific to $P$. balsamifera. However, the lack of either a significant species $\times$ isolate (province) interaction $(P=0.371)$ or a clone (species) $\times$ isolate (province) interaction $(P=0.751)$ makes this possibility unlikely.

A fourth consideration is that the outbreak was due to a wave year (17) phenomenon, a rare situation in which conditions of inoculum availability, host susceptibility, and environmental favorability for infection were such that an extraordinarily high rate of infection occurred. The shape of the canker age distributions (Fig. 1) was inconsistent with this possibility and indicates a progressive increase in disease incidence over time, potentially as a result of a build up of inoculum or an increase in target size as trees grew larger.

The elimination of the four possibilities described above leaves at least two alternatives: (i) because natural stands of $P$. balsamifera are of relatively minor economic importance, this disease has gone largely unnoticed outside of plantations; or (ii) conditions in plantations are different from those in natural stands, such that $P$. balsamifera becomes more susceptible to $S$. musiva.

A potentially important discrepancy between the field and greenhouse studies is that the average disease rating of $P$. balsamifera was greater than that of Northwest in the greenhouse $(P=0.025)$ whereas, in the field, there was no signifi-

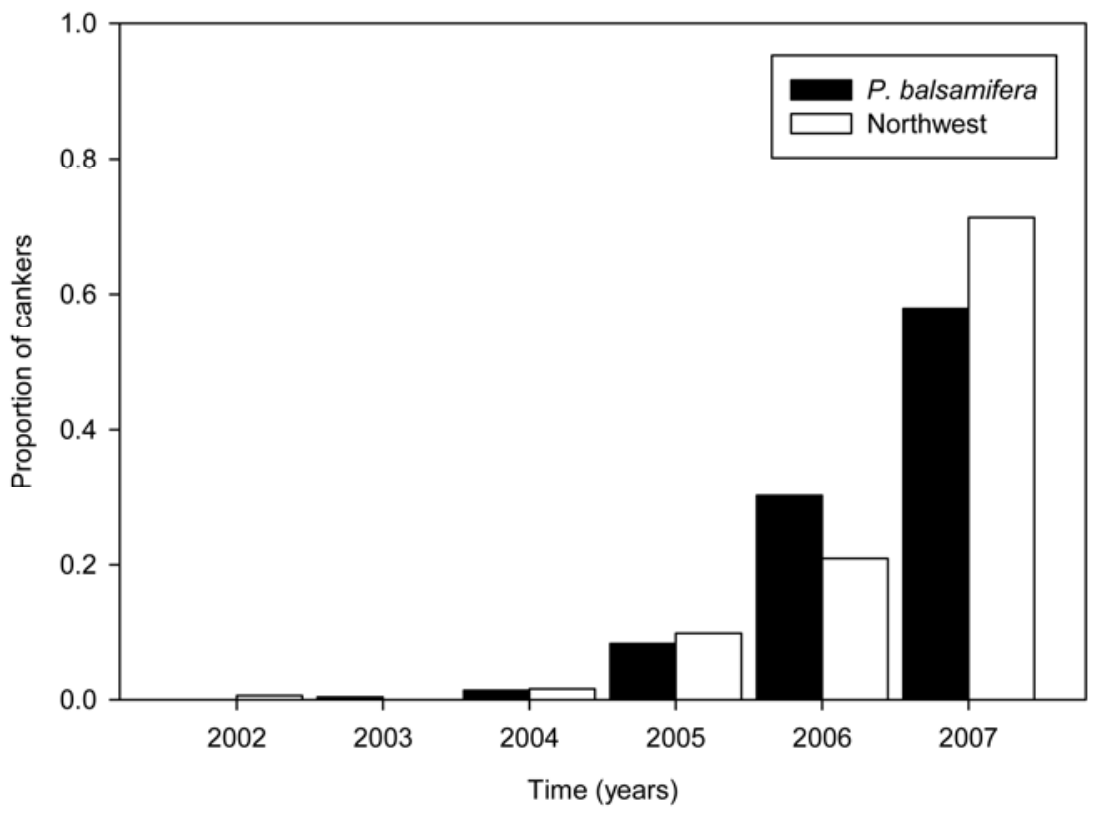

Fig. 1. Canker age distribution for Populus balsamifera (516 cankers) and Northwest (536 cankers) showing the proportion of new cankers each year. Cankers were aged by counting the number of growth rings since symptom appearance.

Table 3. List of Septoria musiva isolates ${ }^{\mathrm{v}}$

\begin{tabular}{|c|c|c|c|c|c|c|}
\hline \multirow[b]{2}{*}{ Isolate } & \multirow[b]{2}{*}{ Origin } & \multirow[b]{2}{*}{ Host, symptom } & \multicolumn{3}{|c|}{ Isolate designation $^{w}$} & \multirow[b]{2}{*}{ Severity $\pm 95 \% \mathrm{CI}^{\mathrm{T}}$} \\
\hline & & & GenBank accession no. ${ }^{x}$ & PCR-RFLP $^{y}$ & Final & \\
\hline APB1 & Alberta & Bal, canker & - & $\mathrm{m}$ & - & $3.35 \pm 0.34$ \\
\hline APB2 & Alberta & Bal, canker & FJ803985 a & $\mathrm{m}$ & $\mathrm{v}$ & $3.30 \pm 0.32$ \\
\hline APB3 & Alberta & Bal, canker & FJ803986 a & $\mathrm{n}$ & $\mathrm{w}$ & $3.45 \pm 0.34$ \\
\hline APB4 & Alberta & Bal, canker & FJ803984 a & o & $\mathrm{x}$ & $3.62 \pm 0.32$ \\
\hline TM2 & Quebec & Hyb, leaf spot & FJ803988 b & - & - & $3.63 \pm 0.32$ \\
\hline QC8 & Quebec & Del, leaf spot & FJ803987 b & $\mathrm{m}$ & $\mathrm{y}$ & $3.37 \pm 0.32$ \\
\hline $\mathrm{SO} 3$ & Quebec & Del, leaf spot & - & $\mathrm{p}$ & $\mathrm{z}$ & $3.60 \pm 0.33$ \\
\hline
\end{tabular}

${ }^{\mathrm{v}}$ Isolate indicates the original collection number given to each isolate. Origin indicates the province of origin of each isolate. Host indicates the host (bal: Populus balsamifera, hyb: hybrid poplar, and del: P. deltoides) and symptom indicates the type of symptom (canker or leaf spot) that the isolate was collected from.

${ }^{\mathrm{w}}$ Isolate designation is divided into three categories: (i) GenBank accession number, which indicates the mitochondrial small subunit ribosomal DNA (mtSSU-rDNA) sequence, where accession numbers marked with the same letter had the same sequence; (ii) polymerase chain reaction restriction fragment length polymorphism (PCR-RFLP) loci, where isolates with the same letter had the same banding pattern; and (iii) final designation, which combines the results of the mtSSU-rDNA sequence and PCR-RFLP analysis, where isolates shown to be different by either method receive different letters. Mean disease severity is the average disease severity of each isolate across all the clones; - indicates isolates not included in the analysis.

${ }^{x}$ Sequence primers NMS 1 and NMS 2 (11).

y PCR-RFLP loci primers Smr2, Smr3, Smr4, Smr6, Smr7, and Smr11 (6).

${ }^{z}$ Mean disease severity $\pm 95 \%$ confidence interval $(\mathrm{CI})$. 
cant difference in the number of cankers per tree $(P=0.726)$ between the two groups. However, in the field study, $16 P$. balsamifera trees were broken versus one Northwest tree, suggesting that, although the frequency of canker formation was similar for both species, $S$. musiva has a greater impact on $P$. balsamifera than Northwest once it has become established within the host.

Most of the variability in resistance was among clones within species in terms of both disease severity (Table 1) and incidence $\left(\sigma_{B}=5.35\right)$. There was very little variability associated with isolates (Table $1)$. This is consistent with findings for $S$. musiva on hybrid poplar $(9,10)$, suggesting that clones should be the focus of any resistance screening program. Furthermore, the absence of species $\times$ isolate and clone (species) $\times$ isolate interactions (Table 1 ) substantiates the statement by Ward and Ostry (21) that there does not appear to be any specific adaptation between this pathogen and any species, cultivars, or hybrid types of Populus. These results have potentially important implications for foresters and poplar breeding programs. It can no longer be assumed that plantations of $P$. balsamifera, within their natural range, will remain free of Septoria canker. Nor can P. balsamifera always be considered resistant parent material for use in breeding programs.

In conclusion, the outbreak of Septoria canker on $P$. balsamifera in northern Alberta does not appear to be caused by either (i) highly virulent isolates, (ii) isolates specific to $P$. balsamifera, or (iii) a rare environmental event that led to high infection levels. Rather, the outbreak may be the result of the increased susceptibility of $P$. balsamifera due to conditions in the plantation. Whatever the cause of the outbreak, $P$. balsamifera, from several different provenances within Alberta and British Columbia, is susceptible to stem infections by $S$. musiva under both greenhouse and plantation conditions.

\section{ACKNOWLEDGMENTS}

We thank P. Périnet and M.-J. Mottet at the Ministère des Ressources Naturelles et de la Faune in
Québec City for the plantation tours and their help in collecting the isolate used in this experiment; D. Kamelchuk and J. Hayward for their help in the collection, propagation, establishment, and growth of the poplar clones as well as the harvesting of the two blocks from the field study; Alberta-Pacific Forest Industries Inc. (Al-Pac), who supplied the cuttings for this experiment; C. Davis for technical expertise in the mtSSU-rDNA sequencing at the Molecular Biology Facility in the Department of Biological Sciences at the University of Alberta; The Natural Science and Engineering Research Council (Canada), Al-Pac, and the Canadian Forest Service for a CFS-NSERC-Industry Forest Research Partnership grant to P. V. Blenis and an IPS scholarship to J. M. LeBoldus, supported by AlPac; West Fraser Timber Co. Ltd. for the West Fraser Scholarship in Enhanced Forest Management; and the two anonymous reviewers who provided comments and suggestions that helped improve the original manuscript.

\section{LITERATURE CITED}

1. Ares, A., and Butierrez, L. 1996. Selection of poplar clones for the lower valley of the Colorado River, Argentina. Forestry 69:75-82.

2. Bier, J. E. 1939. Septoria canker of introduced and native hybrid poplars. Can. J. Res. 17:195204.

3. Callan, B.E., Leal, I., Foord, B., Denis, J. J., and van Oosten, C. 2007. Septoria musiva isolated from the cankered stems in hybrid poplar stool beds, Fraser Valley, British Columbia. Pac. Northwest Fungi 2:1-9.

4. DesRochers, A., and Thomas, B.R. 2003. A comparison of pre-planting treatments on hardwood cuttings of four hybrid poplar clones. New For. 26:17-32.

5. Feau, N., Hamelin, R. C., Vandecasteele, C., Stanosz, G. R., and Bernier, L. 2005. Genetic structure of Mycosphaerella populorum (Anamorph Septoria musiva) populations in northcentral and northeastern North America. Phytopathology 95:608-616.

6. Feau, N. Jacobi, V., Hamelin, R. C., and Bernier, L. 2006. Screening of ESTs from the Septoria musiva (teleomorph Mycosphaerella populorum) for detection of SSR and PCRRFLP markers. Mol. Ecol. Notes 6:356-358.

7. Feau, N. Weiland, J., Stanosz G. R., and Bernier, L. 2005. Specific and sensitive PCR based detection of Septoria musiva, S. populicola, and $S$. populi, the causes of leaf spot and stem canker on poplars. Mycol. Res. 109:1015-1028.

8. Filer, T. H., McCraken, F. I., Mohn, C. A., and Randall, W. K. 1971. Septoria canker on nursery stock of Populus deltoides. Plant Dis. Rep. 55:460-463.

9. Krupinsky, J. M. 1989. Variability in Septoria musiva in aggressiveness. Phytopathology, 79:413-416.

10. LeBoldus, J. M., Blenis, P. V., and Thomas, B.
R. 2008. Clone by isolate interaction in the hybrid poplar-Septoria musiva pathosystem. Can. J. For. Res. 38:1888-1896.

11. Li, K., Rouse, D. I., and German T. L. 1994. PCR primers that allow the intergenic differentiation of ascomycetes and their application to Verticillium spp. Appl. Environ. Microbiol. 60:4324-4331.

12. Littell, R. C., Milliken, G. A., Stroup, W. W., Wolfinger, R. D., and Schabenberger, O. 2006. SAS for Mixed Models, Second Edition. SAS Institute Inc., Cary, NC

13. Mottet, M.-J., Bussières, G., and Vallée, G. 1991. Test précoce pour l'évaluation de la sensibilité de peupliers hybrides au chancre septorien. For. Chron. 67:411-416.

14. Newcombe, G., and Ostry, M. E. 2001 Recessive resistance to Septoria stem canker of hybrid poplar. Phytopathology 91:1081-1084.

15. Newcombe, G., Ostry, M. E., Hubbes, M, Périnet, P., and Mottet, M. J. 2001. Poplar diseases. Pages 249-276 in: Poplar Culture in North America. D. I. Dickman, J. G. Isebrands, J. E. Eckenwalder, and J. Richardson, eds. NRC Research Press, National Research Council of Canada, Ottawa, ON, Canada.

16. Ostry, M. E., and McNabb, H. S., Jr. 1985. Susceptibility of Populus species and hybrids to disease in the north central United States. Plant Dis. 69:755-757.

17. Peterson, R. S. 1971. Wave years of infection by western gall rust on pine. Plant Dis. Rep. 55:163-167.

18. Sinclair, W. A., and Lyon, H. H. 2005. Page 24 in: Diseases of Trees and Shrubs, Second Edition. Comstock Publishing Associates, Cornell University Press, Ithaca, NY.

19. Sivanesan, A. 1990. Mycosphaerella populorum. CMI Description of Pathogenic Fungi and Bacteria. 987:1-2.

20. Stanosz, J. C., and Stanosz, G. R. 2002. A medium to enhance identification of Septoria musiva from poplar cankers. For. Pathol. 32:145-152.

21. Ward, K. T., and Ostry, M. E. 2005. Variation in Septoria musiva and the implications for disease resistance screening of poplars. Plant Dis. 89:1077-1082.

22. Waterman, A. M. 1954. Septoria canker of poplars in the United States. U. S. Dep. Agric. Circ. 947.

23. Weiland, J. E., Stanosz, J. C., and Stanosz, G. R. 2003. Prediction of long-term canker disease damage from the responses of juvenile poplar clones to inoculation with Septoria musiva. Plant Dis. 87:1507-1514.

24. Zalasky, H. 1978. Stem and leaf spot infection caused by Septoria musiva and $S$ populicola on poplar seedlings. Phytoprotection 59:43-50.

25. Zolan, M., and Pukkila, P. 1986. Inheritance of DNA methylation in Coprinus cinereus. Mol. Cell. Biol. 6:195-200. 